\title{
Ranking of substrates based on Piptadenia gonoacantha morphological parameters
}

\author{
Clasificación de sustratos basados en parámetros morfológicos de Piptadenia gonoacantha
}

\author{
Dagma Kratz a*, Ivar Wendling b, Carlos A Stuepp ${ }^{\text {c }}$, Rosimeri de Oliveira Fragoso ${ }^{c}$ \\ *Corresponding author: ${ }^{a}$ Universidade Federal de Mato Grosso, Av. Fernando Corrêa da Costa, 2367, \\ Bairro Boa Esperança, CEP 78060-900, Cuiabá, MT, Brazil, dagkratz@yahoo.com.br

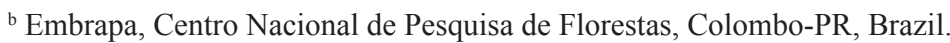 \\ c Universidade Federal do Paraná, Departamento de Fitotecnia e Fitossanitarismo, Curitiba-PR, Brasil.
}

\begin{abstract}
SUMMARY
The definition of best substrates is often difficult due to variability of results observed in different measured variables. Therefore, we defined the best substrates for Piptadenia gonoacantha seedlings production through ranking, taking into account the relative importance of each variable in seedlings quality. In this regard, 13 substrates were formulated, composed of carbonized rice husk in different grain size, coconut fiber and two commercial substrates, pine bark and vermiculite base, all of which had their physical and chemical properties evaluated. Direct seeding was held in containers of $115 \mathrm{~cm}^{3}$, remaining for 90 days in a greenhouse and 30 days in a hardening area with full sunlight. After 120 days, an assessment of height, stem diameter, shoot dry mass, root dry mass, ease of container removal, and aggregation of roots to substrate was performed. As a result, we found higher seedling growth in substrates composed of pure components, which were based on different rice husk grain size. Addition of coconut fiber provided seedlings with lower quality. Pine bark-based commercial substrates occupied the sixth and $12^{\text {th }}$ positions in substrates ranking classification.
\end{abstract}

Key words: pau-jacaré, seedling production, forest seedlings quality, agricultural residues, silviculture.

\section{RESUMEN}

La definición del mejor sustrato es a menudo difícil debido a la variabilidad de los resultados observados en las diferentes variables medidas. Basado en esto, el objetivo fue definir los mejores sustratos para la producción de plántulas de Piptadenia gonoacantha por medio de la clasificación, teniendo en cuenta la importancia relativa de cada variable en la calidad de las plantas. Para este fin, se formularon 13 sustratos a base de cáscara de arroz carbonizado en diferentes tamaños de grano, fibra de coco y corteza de pino compostada, que tenían sus propiedades físicas y químicas evaluadas. Se realizó siembra directa en tubos de $115 \mathrm{~cm}^{3}$, permaneciendo durante 90 días en invernadero de vidrio y 30 días en zona de rustificación a pleno sol. Después de 120 días, se evaluaron la altura, el diámetro del tallo, la biomasa seca aérea, la biomasa seca de las raíces, la facilidad de extracción desde el contenedor y la agregación de las raíces en el sustrato. Como resultado, hay un mayor crecimiento de las plántulas en sustratos compuestos por componentes puros a base de diferentes tamaños de grano de cáscara de arroz. La adición de fibra de coco proporcionó una producción de plántulas con calidad inferior. Los sustratos comerciales basados en corteza de pino ocuparon la posición de sexto y duodécimo en la clasificación de los sustratos.

Palabras clave: pau-jacaré, producción de plántulas, calidad de plántulas forestales, residuos agrícolas, silvicultura.

\section{INTRODUCTION}

Due to legal issues, demand for native forest seedlings is becoming increasingly widespread, especially when referring to adjustment of Legal Reserve and Recovery of Degraded Areas (Brasil 2012, Ribeiro-Oliveira and Ranal 2014). Faced with this situation, the need for large-scale production of plants with quality and reduced costs grows.

Among the species indicated for degraded areas recovery is Piptadenia gonoacantha (Mart.) J.F. Macbr. (Fabaceae), popularly known as pau-jacaré, a pioneer species, native to Atlantic forests, in lowlands and sub montane formations (Souza and Lorenzi 2012) and Seasonal semi- deciduous Forests. More recently, it has attracted interest of the pharmaceutical industry by the presence of asperphenamate, flavonoids and cycloartane with psychotropic and hallucinogenic properties (Carvalho et al. 2010).

Demand for high quality seedlings is with the purpose of the avoidance of mortality losses and low growth rates after planting. Additionally, early high growth rate decreases competition from invasive plants, and management costs (Figueiredo et al. 2011, Dumroese et al. 2011). Seedling quality can be evaluated by measuring shoot height, stem diameter, root development, stem lignification and genetic material (Gomes et al. 2002, Figueiredo et al. 2011). Qualitative variables may be used to assess the quality of 
the root system, such as ease of removal from containers and aggregation of roots to substrate (Wendling et al. 2007).

Several factors can influence plant growth. In the case of cultivation in greenhouses, there is the substrate, which has as functions supporting and supplying water and nutrients needed for plant growth (Hartmann and Kester 2011). The growth media with inadequate physical, chemical and biological characteristics can cause malformations of roots, diseases caused by plant pathogens and presence of undesirable plants (Bakry et al. 2011). Thus, it is essential to choose materials with good physical, chemical and biological quality. Currently a range of substrates is being used for native species seedlings production, with little or no technical information available about them (Dumroese et al. 2011).

There is a range of components available on the market that can be used for substrates formulation, among them are those considered renewable with less environmental impact and low purchase costs (Herrera et al. 2008, Bakry et al. 2011, Kratz et al. 2015). Products such as coconut fiber (Cocos nucifera Linn) and carbonized rice husk (Oryza spp.) are gaining international visibility by the amplitude of supply in several countries, especially Indonesia, Mexico and Brazil (Herrera et al. 2008). In Brazil, the ample supply of carbonized rice husk, especially in producing regions, is subsidizing its use as a component of forest substrates. It is a rather bulky component; only a small portion of it is used as fuel, resulting in an imbalance between its supply and demand, by increasing its world production (Liou and Yang 2011).

Considering the importance of using organic waste and the difficulty to define the best substrates, here, we present the results of an investigation designed to reveal the influence of some substrates toward improving P. gonoacantha seedlings production. We hypothesized that different growth media with different physical and che- mical characteristics result in different patterns of seedlings quality. Through an experiment based on the relative importance of each biometric variable in seedlings quality production, we compared 13 substrates, to define and explain the best substrates by ranking for $P$. gonoacantha seedlings production.

\section{METHODS}

The experiment began in October 2008, in the Laboratory of Forest Species Propagation, from Embrapa Forestry, located in Colombo, Paraná, Brazil (25'19'17' S and $49^{\circ} 09^{\prime} 39^{\prime \prime} \mathrm{W}$ ). The climate, according to international Köppen Climate Classification System, is Cfb (subtropical humid climate) (figure 1).

Two commercial substrates were used based on pine bark (Pinus spp.) and vermiculite (9/1, v:v), and 11 substrates made from coconut fiber and different grain size of carbonized rice husk. For this purpose, we used methodology described by Kratz et al. (2012) (table 1).

Physical and chemical characterization of substrates was performed in Soil Laboratory, Embrapa Forestry, according to the methodology described in the instruction No. 17 of Ministry of Agriculture, Livestock and Food Supply (Mapa 2007).

The materials were manually mixed with a base nutrition $\left(6.6 \mathrm{~kg} \mathrm{~m}^{-3}\right.$ of NPK 4-14-8; $3.3 \mathrm{~kg} \mathrm{~m}^{-3}$ of simple superphosphate $\left[20 \%\right.$ de $\mathrm{P}_{2} \mathrm{O}_{5}$ e $14 \%$ de $\mathrm{SO}_{4}$ ] and $0.8 \mathrm{~kg}$ $\mathrm{m}^{-3}$ of fritted trace elements [7 \% Zn, $4 \% \mathrm{Fe}, 4 \% \mathrm{Mn}$, $0.1 \% \mathrm{Mo}, 2.5 \% \mathrm{~B}, 0.8 \% \mathrm{Cu}])$. The substrates were moistened and placed in plastic tubes of $110 \mathrm{~cm}^{3}$ (packaged interchangeably in metal trays).

Three $P$. gonoacantha seeds were manually distributed per container and subsequently covered with a $0.5 \mathrm{~cm}$ layer of vermiculite. After seeding, they were stowed in a gre-

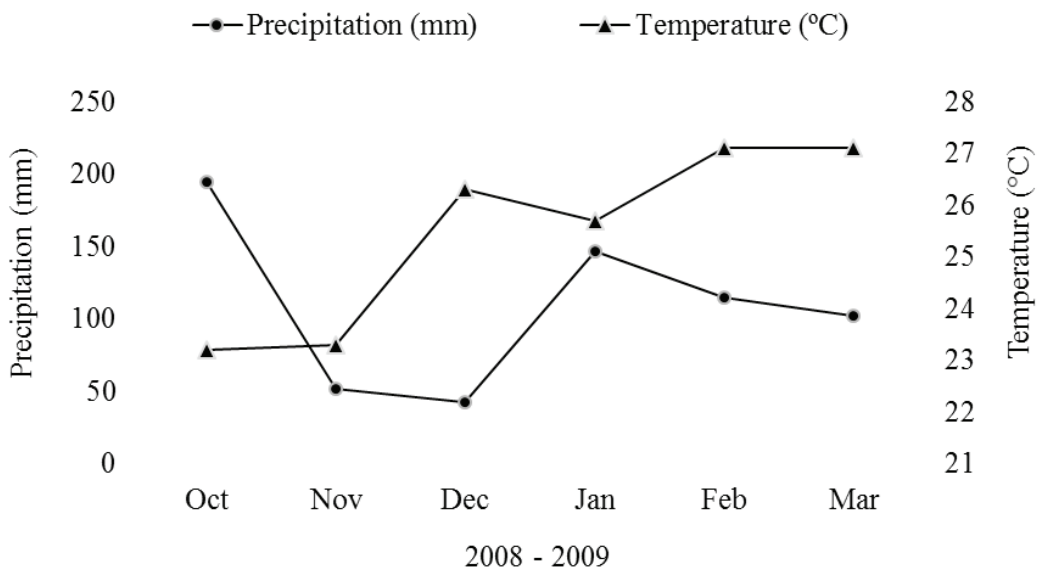

Figure 1. Means of maximum and minimum temperatures and rainfall for Colombo-PR region, between October/2008 and March /2009 (SIMEPAR/PR).

Media de las temperaturas máximas y mínimas y precipitación acumulada para la región de Colombo-PR, entre los meses de octubre/2008 a marzo/2009 (SIMEPAR/PR). 
Table 1. Apparent density (AD), total porosity (TP), macroporosity (Macro), microporosity (Micro), potential of hydrogen (pH), electrical conductivity (EC) and cation exchange capacity (CEC).

Densidad aparente (AD), porosidad total (TP), macroporosidad (Macro), microporosidad (Micro), potencial de hidrógeno (pH), conductividad eléctrica (EC) y la capacidad de intercambio catiónico (CEC).

\begin{tabular}{|c|c|c|c|c|c|c|c|}
\hline \multirow{2}{*}{ Substrate } & $\mathrm{AD}$ & $\mathrm{TP}$ & Macro & Micro & \multirow{2}{*}{$\begin{array}{l}\mathrm{pH} \\
\mathrm{H}_{2} \mathrm{O}\end{array}$} & \multirow{2}{*}{$\begin{array}{c}\mathrm{EC} \\
\mathrm{mS} \mathrm{cm}^{-1}\end{array}$} & \multirow{2}{*}{$\begin{array}{c}\text { CEC } \\
\mathrm{mmol}^{+} \mathrm{dm}^{-3}\end{array}$} \\
\hline & $\mathrm{g} \mathrm{cm}^{3}$ & & $\%$ & & & & \\
\hline CRH & 0.29 & 72.03 & 27.74 & 44.29 & 8.58 & 1.48 & 37.60 \\
\hline CRH1 & 0.19 & 53.08 & 30.25 & 22.83 & 8.51 & 1.26 & 85.60 \\
\hline CRH2 & 0.26 & 63.17 & 32.08 & 31.10 & 8.47 & 1.30 & 68.80 \\
\hline CRH3 & 0.33 & 54.33 & 11.27 & 43.06 & 8.47 & 1.68 & 79.60 \\
\hline CRH4 & 0.32 & 51.98 & 5.32 & 46.66 & 8.44 & 1.94 & 79.80 \\
\hline CRH2/CF (1:1, v:v) & 0.27 & 53.51 & 7.62 & 45.88 & 6.63 & 0.71 & 259.20 \\
\hline CRH3/CF (1:1, v:v) & 0.24 & 54.85 & 14.42 & 40.44 & 6.99 & 0.46 & 210.00 \\
\hline CRH3/CF (9:1, v:v) & 0.23 & 60.38 & 14.48 & 45.89 & 7.72 & 0.29 & 116.20 \\
\hline CRH4/CF (3:1, v:v) & 0.34 & 62.79 & 7.15 & 55.63 & 7.34 & 0.41 & 125.20 \\
\hline CRH4/CF(9:1, v:v) & 0.38 & 61.73 & 5.60 & 56.13 & 7.78 & 0.25 & 103.00 \\
\hline $\mathrm{CF}$ & 0.36 & 60.32 & 16.57 & 43.75 & 8.12 & 1.10 & 127.20 \\
\hline CS1 & 0.49 & 49.31 & 14.38 & 42.93 & 6.06 & 0.76 & 438.40 \\
\hline $\mathrm{CS} 2$ & 0.42 & 47.81 & 3.45 & 44.37 & 5.30 & 1.21 & 359.00 \\
\hline
\end{tabular}

CRH: full carbonized rice husk; CRH1: grain size larger than $2 \mathrm{~mm}$; CRH2: grain size between 1 - $2 \mathrm{~mm}$; CRH3: grain size between 0.5 and $1 \mathrm{~mm}$; CRH4: grain sizes smaller than $0.5 \mathrm{~mm}$; CF: coconut fiber; CS1 and CS2: commercial substrates, pine bark and vermiculite base.

enhouse (three daily irrigations of ten minutes with a flow rate of $144 \mathrm{~L} \mathrm{hour}^{-1}$ ), where they remained for 90 days, followed by a hardening process (four daily irrigations of 30 minutes with a flow rate of $97 \mathrm{~L}$ hour $^{-1}$ ), exposing them to conditions of full sunlight for 30 days. Twenty days after seeding, thinning was performed leaving behind the most centralized and taller seedling in plastic tubes.

Thirty days after seeding, growing nutrition started (4 $\mathrm{g} \mathrm{L}^{-1}$ of urea, $3 \mathrm{~g} \mathrm{~L}^{-1}$ of simple superphosphate, $0.25 \mathrm{~g} \mathrm{~L}^{-1}$ of fritted trace elements [7 \% Zn, $4 \% \mathrm{Fe}, 4 \% \mathrm{Mn}, 0.1 \%$ Mo, $2.5 \% \mathrm{~B}, 0.8 \% \mathrm{Cu}$ ] and $3 \mathrm{~g} \mathrm{~L}^{-1}$ of potassium chloride), performed every seven days until 90 days. After 90 days, next step began, in which seedlings were transferred to full sunlight where hardening fertilizer was applied $\left(4 \mathrm{~g} \mathrm{~L}^{-1} \mathrm{de}\right.$ ammonium sulfate, $10 \mathrm{~g} \mathrm{~L}^{-1}$ of simple superphosphate, 4 $\mathrm{g} \mathrm{L}^{-1}$ of potassium chloride and $1 \mathrm{~g} \mathrm{~L}^{-1}$ of fritted trace elements) every seven days until the $120^{\text {th }}$ day.

To evaluate seedlings quality, measurements of shoot height (ruler) and stem diameter (caliper) at 120 days of all plants were recorded. Destructive analyses (shoot and root dry mass - 48 hours in incubator at $65^{\circ} \mathrm{C}$, or until the material reached constant mass) were performed on five plants per repetition. In the same way, easiness of removal from the container, and roots aggregation of the substrate, following the methodology described by Wendling et al. (2007). From the data collected for height, diameter, shoot and root dry biomass, morphological indices were calcu- lated in relation to height and stem diameter $(\mathrm{H} / \mathrm{SD})$ and shoot dry mass and root dry mass relationship (SDB/RDB).

Experimental design used was completely randomized, with 13 treatments and five repetitions of 10 plants. Data related to biometric characteristics of seedlings were subjected to Bartlett test $(P<0.05)$, to check homogeneity of variance condition; afterwards, analysis of variance (ANOVA) $(P<0.01$ and $P<0.05)$ and proceeding means comparison by the Scott-Knott Test $(P<0.01$ and $P<0.05)$. Pearson Correlation Analysis was applied to check influence of physical and chemical properties of substrates in biometric variables $(P<0.01$ and $P<0.05)$.

The 13 substrates analyzed were ordered according to their technical efficiency for each measured variable. The most efficient substrate being assigned 13 and decreasing values for the others. Definition of relative importance of each variable in seedlings quality was based on studies conducted by Gomes et al. (2002). Weighted sum or technical efficiency was obtained as the following expression [1]:

$$
\begin{array}{r}
\mathrm{Te}=\left(\mathrm{TDB}_{*} 0.40\right)+\left(\mathrm{SDB}_{*} 0.25\right)+\left(\mathrm{RDB}_{*} 0.10\right)+ \\
\left(\mathrm{SD}_{*} 0.10\right)+\left(\mathrm{H}_{*} 0.05\right)+\left(\mathrm{ERC}_{*} 0,05\right)+\left(\mathrm{ARS}_{*} 0.05\right)
\end{array}
$$

Where: $\mathrm{Te}=$ Technical efficiency; $\mathrm{TDB}=$ total dry biomass; $\mathrm{SDB}=$ shoot dry biomass; $\mathrm{RDB}=$ root dry biomass; $\mathrm{SD}=$ stem diameter; $\mathrm{H}=$ height; $\mathrm{ERC}=$ ease of removal from the container; ARS = aggregation of roots to substrate. 
By the end, qualitative ranking was established, where "1" is the most suitable substrate and "13" is the least suitable for $P$. gonoacantha seedlings production.

\section{RESULTS}

A higher technical efficiency of pure components was observed based on different grain size of rice husk. The addition of coconut fiber reduced $P$. gonoacantha seedlings quality. Although based on the same raw material compounds, commercial substrates showed wide differences between them (table 2).

The reduction of the grain size of CRH resulted in a decrease in apparent density and more effectively in the macroporosity of the substrates. On the other hand, it caused a proportional increase in height growth until grain size of 0.5-1 mm (S4- CRH3), which together with CS2, provided the higher increase in seedling height. The use of pure CF or combined with CRH in different grain size did not improve the growth of seedlings. The use of CRH as a pure component in the production of $P$. gonoacantha seedlings is feasible and has high technical efficiency (table 3).

The correlation analysis showed that chemical properties of substrates had a more important effect on seedlings growth in comparison to physical properties (table 4). However, when considering only substrates composed of different grain size of $\mathrm{CRH}$, the effect of physical proper- ties was significant, with little influence from chemical properties, evidenced by slight variation among treatments (table 4, table 1). These results show the influence of different grain size of CRH in P. gonoacantha seedlings growth.

\section{DISCUSSION}

Results obtained for P. gonoacantha demonstrate the possibility of producing seedlings using only one component on substrate formulation (tables 1, 2, 3 and 4). These results for this species are unprecedented and usually the use of two or more components is recommended (Mendoza-Hernandez et al. 2014), mainly not to comprise all desirable physical and chemical characteristics when used alone. Results verified by Boene et al. (2013) and Kratz et al. (2015), with Sebastiania commersoniana and Mimosa scabrella seedlings, respectively, showed superior growth by combining $\mathrm{CRH}$ and $\mathrm{CF}$ when compared to using these as pure components. On the other hand, working with cloned seedlings of $E$. grandis $x$ urophylla, the authors conclude that substrates of pure carbonized rice husk and pure coconut fiber are a viable alternative to produce eucalypt seedlings (Silva et al. 2012).

Small differences presented between original $\mathrm{CRH}$ and substrates CRH2 $(1.0-2.0 \mathrm{~mm})$ and CRH3 $(0.5-1.0 \mathrm{~mm})$ suggests the use of original $\mathrm{CRH}$, taking into account more preparation convenience, leading to production reduced cost.

Table 2. Substrates qualification ranking based on classification of different biometric variables evaluated in $P$. gonoacantha seedlings until 120 days. Where, $\mathrm{H}=$ height, $\mathrm{SD}=$ stem diameter, $\mathrm{TDB}=$ total dry biomass, $\mathrm{SDB}=$ shoot dry biomass, $\mathrm{RDB}=$ root dry biomass, $\mathrm{ERC}=$ ease of removal from the container, $\mathrm{ARS}=$ aggregation of roots to substrate.

Clasificación de sustratos basados en la clasificación de las diferentes variables biométricas evaluadas en plántulas de $P$. gonoacantha hasta 120 días. Donde, $\mathrm{H}=$ altura, $\mathrm{SD}=$ diámetro del tallo, TDB = biomasa seca total, $\mathrm{SDB}=$ biomasa seca aérea, $\mathrm{RDB}=$ biomasa seca de las raíces, $\mathrm{ERC}=$ facilidad de extracción desde el contenedor, ARS = agregación de las raíces en el sustrato.

\begin{tabular}{|c|c|c|c|c|c|c|c|c|}
\hline \multirow{2}{*}{ Substrate } & \multicolumn{7}{|c|}{ Classification/variable } & \multirow{2}{*}{ Weigthed Sum } \\
\hline & $\mathrm{H}$ & $\mathrm{SD}$ & TDB & SDB & RDB & ERC & ARS & \\
\hline $\mathrm{CRH}$ & 7 & 8 & 11 & 11 & 11 & 13 & 12 & 10.65 \\
\hline CRH1 & 4 & 12 & 10 & 7 & 13 & 8 & 2 & 8.95 \\
\hline $\mathrm{CRH} 2$ & 8 & 10 & 13 & 12 & 12 & 5 & 11 & 11.60 \\
\hline CRH3 & 13 & 13 & 12 & 13 & 10 & 4 & 9 & 11.65 \\
\hline CRH4 & 9 & 9 & 9 & 10 & 6 & 12 & 3 & 8.80 \\
\hline CRH2/CF $(1 / 1, v: v)$ & 3 & 5 & 3 & 3 & 3 & 3 & 7 & 3.40 \\
\hline CRH3/CF $(1 / 1, v: v)$ & 1 & 1 & 1 & 2 & 1 & 9 & 4 & 1.80 \\
\hline CRH3/CF (9/1, v:v) & 10 & 6 & 6 & 5 & 7 & 11 & 13 & 6.65 \\
\hline CRH4/CF $(3 / 1, v: v)$ & 2 & 3 & 4 & 4 & 2 & 2 & 5 & 3.55 \\
\hline CRH4/CF(9/1, v:v) & 11 & 4 & 8 & 8 & 9 & 10 & 6 & 7.85 \\
\hline $\mathrm{CF}$ & 6 & 7 & 5 & 6 & 4 & 7 & 10 & 5.75 \\
\hline $\mathrm{CS} 1$ & 5 & 2 & 2 & 1 & 5 & 6 & 1 & 2.35 \\
\hline $\mathrm{CS} 2$ & 12 & 11 & 7 & 9 & 8 & 1 & 8 & 8.00 \\
\hline
\end{tabular}

CRH: full carbonized rice husk; CRH1: grain size larger than $2 \mathrm{~mm}$; CRH2: grain size between 1 - $2 \mathrm{~mm}$; CRH3: grain size between 0.5 and $1 \mathrm{~mm}$; CRH4: grain sizes smaller than $0.5 \mathrm{~mm}$; CF: coconut fiber; CS1 and CS2: commercial substrates, pine bark and vermiculite base. 
Table 3. Height (H), stem diameter (SD), height and stem diameter relationship (H/SD), shoot dry mass (SDB), root dry mass (RDB), shoot aerial mass and root dry mass relationship (SDB/RDB), ease of removal from the container (ERC) and aggregation of the roots to the substrate (ARS) of $P$. gonoacantha seedlings at 120 days, produced in different substrates.

Altura $(\mathrm{H})$, diámetro del tallo (SD), relación entre la altura y el diámetro del tallo (H/SD), biomasa seca aérea (SDB), biomasa seca de la raíz (RDB), relación entre la biomasa seca aérea y de las raíces (SDB/RDB), facilidad de extracción del cartucho (ERC) y la agregación de las raíces en el sustrato (ARS) en plántulas de P. gonoacantha en 120 días, producido en diferentes sustratos.

\begin{tabular}{|c|c|c|c|c|c|c|c|c|}
\hline \multirow{2}{*}{ Substrate } & \multirow{2}{*}{$\begin{array}{c}\mathrm{H} \\
(\mathrm{cm})\end{array}$} & \multirow{2}{*}{$\begin{array}{c}\text { SD } \\
(\mathrm{mm})\end{array}$} & \multirow{2}{*}{$\mathrm{H} / \mathrm{SD}$} & SDB & RDB & \multirow{2}{*}{$\begin{array}{l}\text { SDB/ } \\
\text { RDB }\end{array}$} & \multirow{2}{*}{ ERC } & \multirow{2}{*}{ ARS } \\
\hline & & & & \multicolumn{2}{|c|}{$\left(\right.$ g seedling $\left.^{-1}\right)$} & & & \\
\hline CRH & $11.21 \mathrm{~b}$ & $3.00 \mathrm{a}$ & $4.06 \mathrm{a}$ & $0.55 \mathrm{a}$ & $0.40 \mathrm{~b}$ & $1.40 \mathrm{a}$ & $10.00 \mathrm{a}$ & $8.00 \mathrm{a}$ \\
\hline CRH1 & $10.60 \mathrm{c}$ & $3.25 \mathrm{a}$ & $3.26 \mathrm{a}$ & $0.49 \mathrm{~b}$ & $0.44 \mathrm{a}$ & $1.12 \mathrm{~b}$ & $9.40 \mathrm{a}$ & $4.80 \mathrm{~b}$ \\
\hline CRH2 & $11.50 \mathrm{~b}$ & $3.13 \mathrm{a}$ & $3.73 \mathrm{a}$ & $0.56 \mathrm{a}$ & $0.43 \mathrm{a}$ & $1.34 \mathrm{a}$ & $9.60 \mathrm{a}$ & $7.80 \mathrm{a}$ \\
\hline CRH3 & $13.82 \mathrm{a}$ & $3.25 \mathrm{a}$ & $4.25 \mathrm{a}$ & $0.60 \mathrm{a}$ & $0.39 \mathrm{~b}$ & $1.55 \mathrm{a}$ & $9.60 \mathrm{a}$ & $7.00 \mathrm{a}$ \\
\hline CRH4 & $11.59 \mathrm{~b}$ & $3.03 \mathrm{a}$ & $3.85 \mathrm{a}$ & $0.54 \mathrm{a}$ & $0.32 \mathrm{c}$ & $1.66 \mathrm{a}$ & $10.00 \mathrm{a}$ & $4.80 \mathrm{~b}$ \\
\hline CRH2/CF (1/1, v:v) & $10.30 \mathrm{c}$ & $2.70 \mathrm{~b}$ & $3.82 \mathrm{a}$ & $0.40 \mathrm{c}$ & $0.28 \mathrm{~d}$ & $1.44 \mathrm{a}$ & $9.60 \mathrm{a}$ & $6.60 \mathrm{a}$ \\
\hline CRH3/CF $(1 / 1, v: v)$ & $9.30 \mathrm{c}$ & $2.35 \mathrm{~b}$ & $4.01 \mathrm{a}$ & $0.35 \mathrm{~d}$ & $0.23 \mathrm{~d}$ & $1.48 \mathrm{a}$ & $9.00 \mathrm{~b}$ & $5.20 \mathrm{~b}$ \\
\hline CRH3/CF (9/1, v:v) & $11.63 \mathrm{~b}$ & $2.75 \mathrm{~b}$ & $4.23 \mathrm{a}$ & $0.46 \mathrm{~b}$ & $0.32 \mathrm{c}$ & $1.42 \mathrm{a}$ & $8.80 \mathrm{~b}$ & $8.20 \mathrm{a}$ \\
\hline CRH4/CF (3/1, v:v) & $10.10 \mathrm{c}$ & $2.49 \mathrm{~b}$ & $4.08 \mathrm{a}$ & $0.44 \mathrm{c}$ & $0.26 \mathrm{~d}$ & $1.73 \mathrm{a}$ & $9.60 \mathrm{a}$ & $5.60 \mathrm{~b}$ \\
\hline CRH4/CF(9/1, v:v) & $11.93 \mathrm{~b}$ & $2.68 \mathrm{~b}$ & $4.45 \mathrm{a}$ & $0.50 \mathrm{~b}$ & $0.36 \mathrm{~b}$ & $1.39 \mathrm{a}$ & $8.80 \mathrm{~b}$ & $6.40 \mathrm{a}$ \\
\hline $\mathrm{CF}$ & $10.87 \mathrm{c}$ & $2.75 \mathrm{~b}$ & $3.99 \mathrm{a}$ & $0.46 \mathrm{~b}$ & $0.29 \mathrm{~d}$ & $1.63 \mathrm{a}$ & $9.40 \mathrm{a}$ & $7.40 \mathrm{a}$ \\
\hline CS1 & $10.60 \mathrm{c}$ & $2.39 \mathrm{~b}$ & $4.45 \mathrm{a}$ & $0.32 \mathrm{~d}$ & $0.29 \mathrm{~d}$ & $1.15 \mathrm{~b}$ & $9.40 \mathrm{a}$ & $4.00 \mathrm{~b}$ \\
\hline CS2 & $13.54 \mathrm{a}$ & $3.19 \mathrm{a}$ & $3.96 \mathrm{a}$ & $0.50 \mathrm{~b}$ & $0.33 \mathrm{c}$ & $1.56 \mathrm{a}$ & $9.60 \mathrm{a}$ & $6.60 \mathrm{a}$ \\
\hline CV (\%) & 11.31 & 11.26 & 7.90 & 17.32 & 19.74 & 12.51 & 4.07 & 21.42 \\
\hline
\end{tabular}

Means followed by same letter in column do not differ with Scott-Knott test at $5 \%$ probability. Where, CRH: full carbonized rice husk; CRH1: grain size larger than $2 \mathrm{~mm}$; CRH2: grain size between 1 - $2 \mathrm{~mm}$; CRH3: grain size between 0.5 and $1 \mathrm{~mm}$; CRH4: grain sizes smaller than $0.5 \mathrm{~mm}$; CF: coconut fiber; CS1 and CS2: commercial substrates, pine bark and vermiculite base.

Table 4. Correlations between chemical and physical properties of substrates with biometric variables of $P$. gonoacantha seedling at 120 days for all substrates (A) and for carbonized rice husk based substrates (B).

Correlaciones entre las propiedades físicas y químicas de los sustratos y las variables biométricas de plántulas de $P$. gonoacantha en 120 días para todos los sustratos (A) y sustratos a base de cáscara de arroz carbonizado (B).

\begin{tabular}{|c|c|c|c|c|c|c|}
\hline & $\mathrm{H}$ & $\mathrm{SD}$ & SDB & RDB & $\mathrm{ERC}$ & ARS \\
\hline \multicolumn{7}{|c|}{ All substrates (A) } \\
\hline $\mathrm{AD}$ & $0.28 \mathrm{~ns}$ & $-0.25^{\mathrm{ns}}$ & $-0.20^{\mathrm{ns}}$ & $-0.30^{\mathrm{ns}}$ & $0.09 \mathrm{~ns}$ & $-0.22 \mathrm{~ns}$ \\
\hline $\mathrm{TP}$ & $-0.16^{\mathrm{ns}}$ & $-0.04^{\mathrm{ns}}$ & $0.34^{\mathrm{ns}}$ & $0.26^{\mathrm{ns}}$ & $0.04^{\mathrm{ns}}$ & $0.61^{*}$ \\
\hline Macro & $-0.24^{\mathrm{ns}}$ & 0.29 ns & $0.20^{\mathrm{ns}}$ & $0.58^{*}$ & $0.12^{\mathrm{ns}}$ & $0.27^{\mathrm{ns}}$ \\
\hline Micro & $0.11^{\mathrm{ns}}$ & $-0.46^{\mathrm{ns}}$ & $-0.11^{n s}$ & $-0.50^{\mathrm{ns}}$ & $-0.11^{\mathrm{ns}}$ & 0.03 ns \\
\hline $\mathrm{CEC}$ & $-0.09^{n s}$ & $-0.42^{\mathrm{ns}}$ & $-0.70^{* *}$ & $-0.55^{*}$ & $-0.12^{\mathrm{ns}}$ & $-0.36^{\mathrm{ns}}$ \\
\hline $\mathrm{EC}$ & $0.45^{\mathrm{ns}}$ & $0.75^{\text {** }}$ & $0.66^{*}$ & $0.51^{\mathrm{ns}}$ & $0.79^{* *}$ & $0.02^{\text {ns }}$ \\
\hline \multicolumn{7}{|c|}{ Different carbonized rice husk grain sizes (B) } \\
\hline $\mathrm{AD}$ & $0.73^{* *}$ & $-0.38^{n s}$ & $0.79^{* *}$ & $-0.77^{* *}$ & $0.65^{*}$ & $0.28^{\mathrm{ns}}$ \\
\hline $\mathrm{TP}$ & $-0.23^{\mathrm{ns}}$ & $-0.56^{*}$ & $0.17^{\mathrm{ns}}$ & $0.28^{\mathrm{ns}}$ & $0.40^{\mathrm{ns}}$ & $0.83^{* *}$ \\
\hline Micro & $0.50^{\mathrm{ns}}$ & $-0.61^{*}$ & $0.59^{*}$ & $-0.84^{* *}$ & $0.85^{* *}$ & $0.22^{\mathrm{ns}}$ \\
\hline $\mathrm{pH}$ & $-0.38^{\mathrm{ns}}$ & $-0.27^{\mathrm{ns}}$ & $-0.21^{\mathrm{ns}}$ & $0.42^{\mathrm{ns}}$ & $0.17^{\mathrm{ns}}$ & $0.44^{\mathrm{ns}}$ \\
\hline $\mathrm{CEC}$ & $0.19^{\mathrm{ns}}$ & $0.69^{* *}$ & $-0.18^{\mathrm{ns}}$ & $-0.05 \mathrm{~ns}$ & $-0.60^{*}$ & $-0.73^{* *}$ \\
\hline $\mathrm{CE}$ & $0.46^{\mathrm{ns}}$ & $-0.37 \mathrm{~ns}$ & $0.35^{\mathrm{ns}}$ & $-0.98^{* *}$ & $0.65^{*}$ & $-0.30^{\mathrm{ns}}$ \\
\hline
\end{tabular}

" and ${ }^{* *}$ significant at $5 \%$ and $1 \%$ error probability, respectively, and ${ }^{\mathrm{ns}}$ no significant at $5 \%$ error probability by F test. Where, H: height; SD: stem diameter; SDB: shoot dry biomass; RDB: root dry biomass; ERC: ease of removal from the container; ARS: aggregation of the roots to the substrate; AD: Apparent density; TP: total porosity; Macro: macroporosity; Micro: microporosity; $\mathrm{pH}$ : potential of hydrogen; EC: Electrical conductivity and CEC: cation exchange capacity. 
Regarding the different grain size of $\mathrm{CRH}$, increased density and reduced macroporosity were found to lead to an increase in height growth as well as shoot and root dry mass accumulation (table 3). On the other hand, it provided an increase in the easiness of removal from the container as a result of low roots aggregation to substrate and lack of structure of carbonized rice husk, enhanced by reduction in grain size (tables 2 and 3 ).

The increase in macroporosity of substrates favored root dry mass (tables 1,2 and 3). This shows the importance of oxygen availability to root system, favored by increase in macropores (Mendoza-Hernández et al. 2014).

The low aggregation observed in CRH 1 and $\mathrm{CRH} 4$ substrates is the result of lack of structure of these components, considering they represent the largest and smallest grain size of CRH analyzed (table 3). A good index of aggregation is an excellent parameter of substrate quality for seedling production, favoring when performing activities in nursery and planting in field, thereby avoiding disintegration of formed root system (Wendling et al. 2007). Results illustrate positive relationship between electrical conductivity and biomass accumulation (table 4). This response is due to the larger amount of soluble ions (BasileDoelsch et al. 2007). It is noteworthy that excessive rise in electrical conductivity can be detrimental to the development of seedlings (Fornes et al. 2010).

The $\mathrm{pH}$ was positively correlated with shoot and root biomass accumulation (table 4). According to Belda et al. (2013), optimal $\mathrm{pH}$ values fall in a range between 5.0 and 6.5. However, only the commercial substrates remained in this range, possibly due to the presetting, which is common for commercial substrates (Carrión et al. 2008). Conversely, in case of controlled production in nursery and with adequate availability of nutrients in each step, it can be carried out over a wide $\mathrm{pH}$ range (Fornes et al. 2010, Mendoza-Hernández et al. 2014). It is important to note that the species occurs predominantly on calcareous soils, thus justifying its results in alkaline $\mathrm{pH}$ (Aidar et al. 2001).

Cation exchange capacity was negatively correlated with shoot and root biomass because coconut fiber based substrates, despite the higher CEC, showed lower seedlings growth (table 4).

Commercial substrates based on semi-decomposed pine bark differed for all biometric variables (table 3). Semi-decomposed pine bark has been widely used and its technical feasibility has been proven in many researches (Scheer et al. 2012, Boene et al. 2013). However, this substrate was not the most suitable for Gleditschia amorphoides (Bortolini et al. 2012), Eucalyptus urophylla $\mathrm{x}$ E. grandis (Rocha et al. 2013) and E. grandis (Oliveira et al. 2008) seedlings production. Different results observed refer to variations in physical and chemical properties of substrates, which is directly connected to preparation form, particularly decomposition time (Wendling et al. 2007). This variation has a direct effect on plant growth.
Regarding reasonable growth results obtained with commercial substrates, there is nowadays low pine bark supply for substrates manufacture due to its use as an energy source for boilers in forest industries calderas, associated with Pinus spp. planted areas reduction in Brazil (Furtado et al. 2012). This highlights the need for studies aiming at development of other materials for use as substrates.

\section{CONCLUSIONS}

We conclude that a classification method based on biometric variables is feasible to determine the best substrates for $P$. gonoacantha seedlings production and, when substrates with different compositions are compared, chemical properties of substrates have a superior effect on seedlings growth in comparison to physical properties.

Based on the relative importance of each biometric variable in seedlings quality, the best substrates for $P$. gonoacantha seedlings production are those composed of pure components with different rice husk grain size; the addition of coconut fiber reduces the quality of $P$. gonoacantha seedlings.

\section{REFERENCES}

Aidar MPR, JRL Godoy, J Bergmann, CA Joly. 2001. Atlantic Forest succession over calcareous soil, Parque Estadual Turístico do Alto Ribeira - PETAR, SP. Revista Brasileira de Botanica 24(4):455-469. DOI: 10.1590/S010084042001000400012

Bakry M, MS Lamhamedi, J Caron, HEL Margolis, AZ Abidine, M Bellaka, DC Stowe. 2011. Are composts from shredded leafy branches of fast-growing forest species suitable as nursery growing media in arid regions? New Forests 43(3): 267-286. DOI: 10.1007/s11056-011-9280-x

Basile-Doelsch I, R Amundson, WEE Stone, D Borschneck, JY Bottero, S Moustier, F Masin, F Colin. 2007. Mineral control of carbon pools in a volcanic soil horizon. Geoderma 137(3-4): 477-489. DOI: 10.1016/j.geoderma.2006.10.006

Belda RM, D Mendoza-Hernández, F Fornes. 2013. Nutrientrich compost versus nutrient-poor vermicompost as growth media for ornamental-plant production. Journal of Plant Nutrition and Soil Science 176(6): 827-835. DOI: 10.1002/ jpln. 201200325

Boene HCAM, AC Nogueira, NJ Sousa, D Kratz, PVD Souza. 2013. Efeitos de diferentes substratos na produção de mudas de Sebastiania commersoniana. Floresta 43(3): 407-420.

Bortolini MF, HS Koehler, KC Zuffellato-Ribas, AMT Fortes. 2012. Crescimento de mudas de Gleditschia amorphoides Taub. produzidas em diferentes substratos. Ciência Florestal 22(1): 35-46. DOI: 10.5902/198050985077

Brasil. 2012. Lei $\mathrm{n}^{\mathrm{o}}$ 12.651. Código Florestal. Consulted 07 abr. 2015. Available in www.planalto.gov.br/ccivil_03/ ato2011-2014/2012/lei/112651.htm

Carrión C, R García-De-La-Fuente, F Fornes, R Puchades, M Abad. 2008. Acidifying compost from vegetable crop wastes to prepare growing media for containerized crops. Compost Science and Utilization 16(1): 20-29. DOI: 
10.1080/1065657X.2008.10702351

Carvalho MG, MAR Cardozo, FEA Catunda Junior, AG Carvalho. 2010. Chemical constituents of Piptadenia gonoacantha (Mart.) J.F. Macbr (pau jacaré). Anais da Academia Brasileira de Ciências 82(3): 561-567. DOI: 10.1590/ S0001-37652010000300003

Dumroese RK, J Heiskanen, K Englund, A Tervahauta. 2011. Pelleted biochar: Chemical and physical properties show potential use as a substrate in container nurseries. Biomass and Bioenergy 35(5): 2018-2027. DOI: 10.1016/j.biombioe. 2011.01 .053

Figueiredo FAMM, JGA Carneiro, RM Penchel, DG Barroso, RF Daher. 2011. Efeito das variações biométricas de mudas clonais de eucalipto sobre o crescimento no campo. Revista Árvore 35(1): 1-11. DOI: 10.1590/S010067622011000100001

Fornes F, C Carrión, R García-De-La-Fuente, R Puchades, M Abad. 2010. Leaching composted lignocellulosic wastes to prepare container media: feasibility and environmental concerns. Journal of Environmental Management 91(8): 1747-1755. DOI: 10.1016/j.jenvman.2010.03.017. Epub 2010 Apr 24

Furtado TS, JC Ferreira, MA Brand, MD Neves. 2012. Correlação entre teor de umidade e eficiência energética de resíduos de Pinus taeda em diferentes idades. Revista Árvore 36(3): 577-582. DOI: 10.1590/S0100-67622012000300020

Gomes JM, L Couto, HG Leite, A Xavier, SL Garcia. 2002. Parâmetros morfológicos na avaliação da qualidade de mudas de Eucalyptus grandis. Revista Árvore 26(6): 655-664. DOI: 10.1590/S0100-67622002000600002

Hartmann HT, DE Kester, FT Dvies Jr, RL Geneve. 2011. Plant Propagation: principles and practices. Boston, USA. Prentice Hall. 915 p.

Herrera F, JE Castillo, AF Chica, L López Bellido. 2008. Use of municipal solid waste compost (MSWC) as a growing medium in the nursery production of tomato plants. Bioresource Technology 99(2): 287-296. DOI: 10.1016/j.biortech.2006.12.042

Kratz D, AC Nogueira, I Wendling, PVD Souza. 2015. Substratos renováveis para produção de mudas de Mimosa scabrella. Revista Floresta 45(2): 393-408. DOI: 10.5380/ rf.v45i2.31249

Kratz D, I Wendling, PP Pires. 2012. Miniestaquia de Eucalyptus benthamii x $E$. dunnii em substratos a base de casca de arroz carbonizada. Scientia Forestalis 40(96): 547-556.
Liou TH, CC Yang. 2011. Synthesis and surface characteristics of nanosilica produced from alkali-extracted rice husk ash. Materials Science and Engineering B 176(7): 521-529. DOI: 10.1016/j.mseb.2011.01.007

Mapa (Ministério da Agricultura, Pecuária e Abastecimento, BR). 2007. Métodos Analíticos Oficiais para Análise de Substratos para Plantas e Condicionadores de Solo. Brasilia, Brasil. Consulted 10 Jun. 2010. Available in http:// www.jusbrasil.com.br/diarios/579346/pg-8-secao-1-diariooficial-da-uniao-dou-de-24-05-2007

Mendoza-Hernández D, F Fornes, RM Belda. 2014. Compost and vermicompost of horticultural waste as substrates for cutting rooting and growth of rosemary. Scientia Horticulturae 178: 192-202. DOI: 10.1016/j.scienta.2014.08.024

Oliveira RN, JS Souza Lima, CA Martinelli de Souza, S de Assis Silva, S Martins Filho. 2008. Produção de mudas de essências florestais em diferentes substratos e acompanhamento do desenvolvimento em campo. Ciência e Agrotecnologia 32(1): 122-128.

Ribeiro-Oliveira JP, MA Ranal. 2014. Sementes florestais brasileiras: início precário, presente inebriante e o futuro, promissor? Ciência Florestal 24(3): 771-784. DOI: $10.5902 / 1980509815738$

Rocha JHT, C Backes, FA Diogo, CB Pascotto, K Borelli. 2013. Composto de lodo de esgoto como substrato para mudas de eucalipto. Pesquisa Florestal Brasileira 33(73): 27-36. DOI: 10.4336/2013.pfb.33.73.331

Scheer MB, C Carneiro, OA Bressan, KG Santos. 2012. Compostos de lodo de esgoto para a produção de mudas de Anadenanthera colubrina (Vell.) Brenan. Cerne 18(4): 613-621. DOI: 10.1590/S0104-77602012000400011

Silva RBG, D Simões; MR Silva. 2012. Qualidade de mudas clonais de Eucalyptus urophylla x E. grandis em função do substrato. Revista Brasileira de Engenharia Agrícola e Ambiental 16(3): 297-302. DOI: 10.1590/S141543662012000300010

Souza VC, H Lorenzi. 2012. Botânica Sistemática: guia ilustrado para identificação das famílias de Fanerógamas e nativas e exóticas no Brasil, baseado em APG III. São Paulo, Brasil. Instituto Plantarum. 768 p.

Wendling I, D Guastala, R Dedecek. 2007. Características físicas e químicas de substratos para produção de mudas de Ilex paraguariensis St. Hil. Revista Árvore 31(2): 209-220. DOI: 10.1590/S0100-67622007000200003

Recibido: 01.10.15

Aceptado: 21.01.16 
